\title{
Nobel Prize given for work on protein phosphorylation
}

Two US biochemists have won the 1992 Nobel Prize in Physiology or Medicine for discovering a fundamental mechanism that regulates cell metabolism. In a series of experiments starting in the 1950s, Edwin Krebs and Edmond Fischer, both of the University of Washington, Seattle, characterized protein kinases, a class of enzyme that change pro-

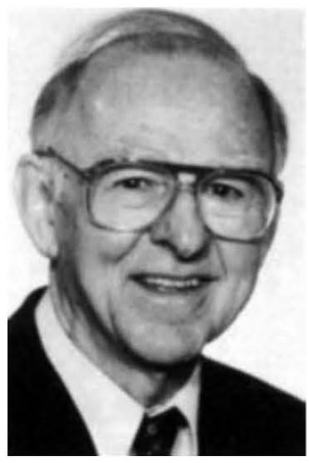

Edwin Krebs teins from their inactive to their active form by speeding the chemical bonding of a phosphate group to the protein. This transfer, or phosphorylation, is the underlying 'life switch' that starts and stops a variety of cell functions, from the breakdown of fats

to the generation of chemical energy, in response to hormonal and other signals.

Working on muscle tissue, Krebs (who is unrelated to Hans Krebs, another Nobel laureate who described in the $1930 \mathrm{~s}$ the citric acid cycle of metabolism that bears his name) and Fischer showed that protein kinases regulate phosphorylation by catalyzing a reaction in which a phosphate group is transferred from the energy-carrying compound ATP to a protein, thereby activating the protein and contracting the muscle. Hundreds of new protein kinases have since been found, and researchers esti- mate that perhaps one per cent of the genes in the human genome code for protein kinases of one sort or another.

More recently, the two scientists and their colleagues have identified some of the key enzymes - called phosphatases - - that catalyze the transfer of energy in the other direction by removing phosphate groups from proteins. Combined, this mechanism for transferring phosphate groups to and from a protein to turn it on or off is known as reversible protein phosphorylation, and it is for the characterization of this fundamental process involving both kinases and phosphatases that the Nobel Prize committee is honouring the two biochemists.

Krebs won a Lasker award in 1989 for his research; both men are members of the US National Academy of Sciences. About one-third (46 in all) of Lasker winners go on to win a Nobel Prize, making it one of the best predictors of future Nobel laureates. At the time Krebs and Fischer did their work, researchers did not appreciate the significance of protein kinases as a regulatory mechanism.

Krebs, 74, and Fischer, 72, are still active researchers. In 1988, Fischer and his group proved that surface proteins of CD45 Tcells work on the same principle as a phosphatase, removing phosphate groups from an enzyme and starting a cascade in which other enzymes (including some detected by Krebs) are activated. This insight into the human immune system has helped researchers to learn how immune-suppressing drugs prevent the body from rejecting organ transplants.

Christopher Anderson

\section{NOAA appoints ombudsman to repair frayed ties with universities}

Washington. Hoping to mend its tattered reputation among academic researchers, the US National Oceanic and Atmospheric Administration (NOAA) has turned to an old standby: the complaints desk. Last month, William Hooke, the deputy chief scientist at the agency, was appointed to the new position of ombudsman and given a mandate to untangle red tape and otherwise help scientists to deal with unresponsive officials and waylaid grants from the agency's \$100million extramural research programme.

In his first few weeks, Hooke, a veteran NOAA official with a good reputation among academic scientists, has already managed to release a handful of grants that were held up by the bureaucracy. And so far, Hooke says, he has been able to resolve most complaints within 24 hours.

Academic scientists who have seen other NOAA reforms founder say that it is too early to pass judgement on the latest effort. But Christopher Mooers, a University of Miami oceanographer, believes that an ombudsman may help NOAA to solve its frustrating tendency to allow worthy grant proposals to become bogged down in a patchwork administrative structure that requires several offices to give their approval. An ombudsman may not make NOAA run on a clock more conducive to an academic researcher, but for the first time the agency has designated someone whose job it is to argue on their behalf.

\section{Perkin-Elmer to buy Applied Biosystems to broaden markets}

Washington. Applied Biosystems, Inc. of Foster City, California, a leading supplier of automated DNA and protein systems for life-science research, announced last week that it is to become part of Perkin-Elmer Corporation, a manufacturer of analytical instrumentation based in Norwalk, Connecticut.

The deal, which is valued at about $\$ 330$ million, brings together two companies with closely related technologies. Perkin-Elmer acquired exclusive worldwide rights to market Hoffmann-La Roche's polymerase chain reaction (PCR) technology for nondiagnostic purposes after Hoffmann-La Roche bought the technology from Cetus Corporation in July 1991 for $\$ 300$ million (see Nature $\mathbf{3 5 2}$, 364; 1991).

The PCR technology goes "hand-in-hand with our DNA analysis and synthesis technology", says André Marion, chairman and chief executive officer of Applied Biosystems.

Applied Biosystems was founded in 1981 by Marion and Sam Eletr and employs 1,200 people. It reported total annual sales this year of $\$ 183$ million compared with $\$ 164$ million last year, although the company reported a net loss in both years.

Sales of products for DNA research increased 31 per cent over 1991 levels and now account for more than 60 per cent of total sales. However, sales of the company's protein products declined, reflecting an industry-wide slump. PerkinElmer was founded in 1937, employs 6,000 people worldwide and earned $\$ 58$ million this year on annual sales of $\$ 911$ million.

The move will enable Applied Biosystems to tap into emerging markets such as agriculture, animal husbandry, environmental testing, forensic science and paternity testing. In total, these new markets are larger than the research market that the company now serves.

Under the terms of the stock swop, PerkinElmer will exchange 0.678 shares of its stock for each share of Applied Biosystems' stock. The day after the announcement, Perkin-Elmer's share price closed down $\$ 1$ $1 / 2$ at $\$ 291 / 2$; Applied Biosystems was up $\$ 23 / 8$ at $\$ 193 / 8$.

The newly formed group will be called the Applied Biosystems Life Science Division of Perkin-Elmer and will assume overall responsibility for Perkin-Elmer's life science business, including its PCR amplification technology. The acquisition must still be approved by shareholders and various regulatory authorities but is expected to be completed early next year.

Diane Gershon 